\title{
KARAKTERISTIK KIMIA DAN ORGANOLEPTIK KERUPUK JANTUNG PISANG KEPOK (Musa Paradisiaca balbisiana) DENGAN SUBSTITUSI TEPUNG MOCAF (MODIFIKASI CASSAVA)
}

\author{
CHEMICAL AND SENSORY CHARACTERISTIK OF KEPOK BANANA FLOWER CRISPY \\ (Musa Paradisiaca balbisiana) SUBTITUTED BY MOCAF FLAVOR (MODIFICATION \\ CASSAVA)
}

Fitriyah Zulfa, Susi Mudzakiroh

Program Studi Teknologi Hasil Pertanian PDD UNS

Email fitriyah_zulfa@yahoo.ie

Diserahkan [10 Agustus 2017]; Diterima [10 Desember 2017]; Dipublikasi [26 Februari 2018]

\begin{abstract}
Kerupuk is the most favourite snack in Indonesia. Kepok Banana flower (musa paradisiaca balbisiana) as the base componen of kerupuk bananan flower to up grade the economic margin. Substitution mocaf flavor from tapioca flavor to produce kerupuk without gluten. This research aim is to know chemical and organoleptic characteristic kerupuk bananan flower substituted with mocaf (modificated cassava). This product use banana kepok flower, mocaf with formula 90\%:10\%. Blend banana flower to smallest size, mix with mocaf and spice, steam 5 minute, and dry with cabinet drying 6 hour $50^{\circ} \mathrm{C}$ to proseses it. Chemical characteristic show water level is 2\%, protein is $0,37 \%$ and viber is $7 \%$. Organoleptic characteristic of banana flower with sensory analisis show mean score colour 5,2 (nearly like), score taste 6 (like), score tecsture 5,8 (like), score shape 4,7 (nearly like)and overall score are 5,7 (like). Suggested to make more innovation to produce banana flower mocaf crispy with more attractive in colour and shape.
\end{abstract}

Keyword: crackers, banana heart, mocaf, moisture content, protein, fiber, sensory

\begin{abstract}
ABSTRAK
Kerupuk merupakan camilan favorit di semua daerah di Indonesia. Pemanfaatan jantung pisang kapok (musa paradisiaca balbisiana) sebagai bahan dasar pembuatan kerupuk jantung pisang untuk meningkatkan nilai jual jantung pisang yang selama ini tidak banyak dimanfaatkan. Penambahan tepung mocaf sebagai substitusi tepung tapioca untuk menghasilkan kerupuk yang free gluten sehingga aman dikonsumsi penderita autis. Penelitian bertujuan mengetahui karakteristik kimia dan organoleptik kerupuk jantung pisang kapok (musa paradisiacal bilbisiana) dengan substitusi tepung mocaf (modifikasi cassava). Bahan yang digunakan adalah jantung pisang kapok, mocaf, bumbu dan minyak dengan formula 90\%:10\%, alat yang digunakan adalah baskom, neraca analitik, steamer, dan cabinet drying. Proses pembuatan dengan membuat adonan kerupuk lalu steam dan pengeringan di cabinet drying selama 6 jam suhu $50^{\circ} \mathrm{C}$. Karakteristik kimia menunjukkan kadar air 2 $\%$, protein $0,37 \%$ dan serat $7,00 \%$. Karakteristik organoleptik dengan analisa sensori menunjukkan rata-rata skor warna 5,2 (agak suka), skor rasa 6 (suka), skor tekstur 5,8 (suka), skor bentuk 4,7 (agak suka) dan secara keseluruhan suka (rata-rata skor 5,7) terhadap kerupuk jantung pisang mocaf. Disarankan inovasi lebih untuk menghasilkan kerupuk jantung pisang mocaf yang memiliki warna dan bentuk lebih menarik konsumen.
\end{abstract}

Kata Kunci: kerupuk, jantung pisang, mocaf, kadar air, protein, serat, sensori.

\section{PENDAHULUAN}

Kerupuk adalah salah satu jenis makanan ringan yang cukup banyak diminati oleh berbagai kalangan, baik digunakan sebagai makanan pendamping atau sebagai camilan. Kerupuk banyak dijumpai diberbagai daerah di Indonesia. Bahkan hampir disetiap warung atau supermarket juga disediakan krupuk dengan berbagai macam merek dan rasa. Kerupuk yang sering dijumpai biasanya terbuat dari ikan atau kulit dengan bahan baku ikan dan tepung tapioka. Penulis mencoba untuk membuat inovasi kerupuk dengan bahan dasar jantung pisang dan disubtitusikan dengan tepung mocaf.

Tepung mocaf merupakan tepung hasil modifikasi dari ubi kayu yang dibuat dengan cara difermentasi. Tepung mocaf memiliki beberapa kelebihan tersendiri dibanding tepung yang lainnya, diantara free gluten sehingga aman dikonsumsi untuk penderita autis. Tepung mocaf juga memiliki warna yang lebih putih dan lebih lembut jika dibanding dengan tepung singkong sehingga saat diolah menjadi kerupuk akan berwarna lebih cerah. Dari segi ekonomi, harga dari tepung mocaf cukup minim jika 
dibandingkan dengan tepung terigu, sehingga akan lebih ekonomis untuk proses produksi kerupuk.

Disaat semakin populernya makanan instan dan makanan barat, keberadaan jantung pisang seakan semakin tersingkirkan. Bahkan jantung pisang dianggap menu makanan kalangan menengah ke bawah. Keberadaan jantung pisang yang semakin terlupakan, perlu dilihat sisi lain dari manfaat jantung pisang. Jantung pisang mengandung berbagai zat yang baik bagi kesehatan seperti protein, fosfor, mineral, kalsium vitamin B1, C dan kandungan serat yang cukup tinggi (Panji $\mathrm{R}, 2012$ ).

Saat ini jantung pisang jarang dimanfaatkan khususnya diolah menjadi berbagai makanan. Di daerah pedesaan jantung pisang hanya dimanfaatkan sebagai lauk pauk, baik ditumis atau dibuat botok. Maka dari itu penulis mencoba membuat olahan baru dari jantung pisang dengan dibuat menjadi kerupuk. Dengan diolahnya menjadi kerupuk maka daya simpan jantung pisang akan lebih lama dalam upaya ketahanan pangan masyarakat. Penelitian ini bertujuan untuk mengetahui karakteristik kimia (kadar air, protein, dan serat) dan organoleptik kerupuk jantung pisang kepok (Musa paradisiana bilbisiana) dengan substitusi tepung mocaf.

\section{METODE PENELITIAN}

\section{Bahan}

Bahan yang digunakan dalam pembuatan kerupuk jantung pisang mocaf yaitu jantung pisang, tepung mocaf, tepung tapioca, bumbu, dan minyak goreng.

Alat

Alat yang digunakan dalam pembuatan kerupuk jantung pisang mocaf yaitu baskom, pisau, Loyang, neraca analitik, blender, pengukus, cabinet drying, dan wajan.

\section{Pembuatan Keripik Jantung Pisang Mocaf}

Jantung pisang yang sudah matang diblanching steam selama 10 menit, selanjutnya dipotong-potong untuk mengecilkan ukuran. Lalu direbus sampai lunak (15 menit). Selanjutnya adalah proses penghalusan jantung pisang dengan menggunakan Blender. Jantung pisang yang sudah halus dicampur dengan tepung mocaf, tepung tapioca dan bumbu. Lalu adonan dibungkus daun pisang dan dikukus 15 menit, pendinginan, pencetakan. Selanjutnya dikeringkan dalam cabinet drying selama 6 jam suhu $50^{\circ} \mathrm{C}$ sehingga menjadi kerupuk kering siap digoreng.

Formula yang menyusun adonan kerupuk jantung pisang mocaf adalah campuran jantung pisang dan tepung mocaf dengan perbandingan 90\%:10\%.

Proses pembuatan kerupuk jantung pisang mocaf dijelaskan dalam Gambar 1.

\section{Pengujian Kerupuk Jantung Pisang Mocaf}

Dalam pengujian analisa sensori kerupuk jantung pisang mocaf indera yang digunakan adalah penglihatan, pengecapan dan pendengaran karena parameter yang diuji meliputi warna, bentuk, tekstur, rasa dan penerimaan keseluruhan dari kerupuk yang dihasilkan.

Analisa kimia merupakan pengujian terhadap produk yang dilakukan untuk mengetahui sifat fungsional dari produk dari kerupuk jantung pisang mocaf yang dihasilkan yaitu kandungan kadar air dengan metode oven kering (thermogravimetri), protein (dengan Titrasi formol) dan kadar serat kasar (dengan metode ekstraksi). 


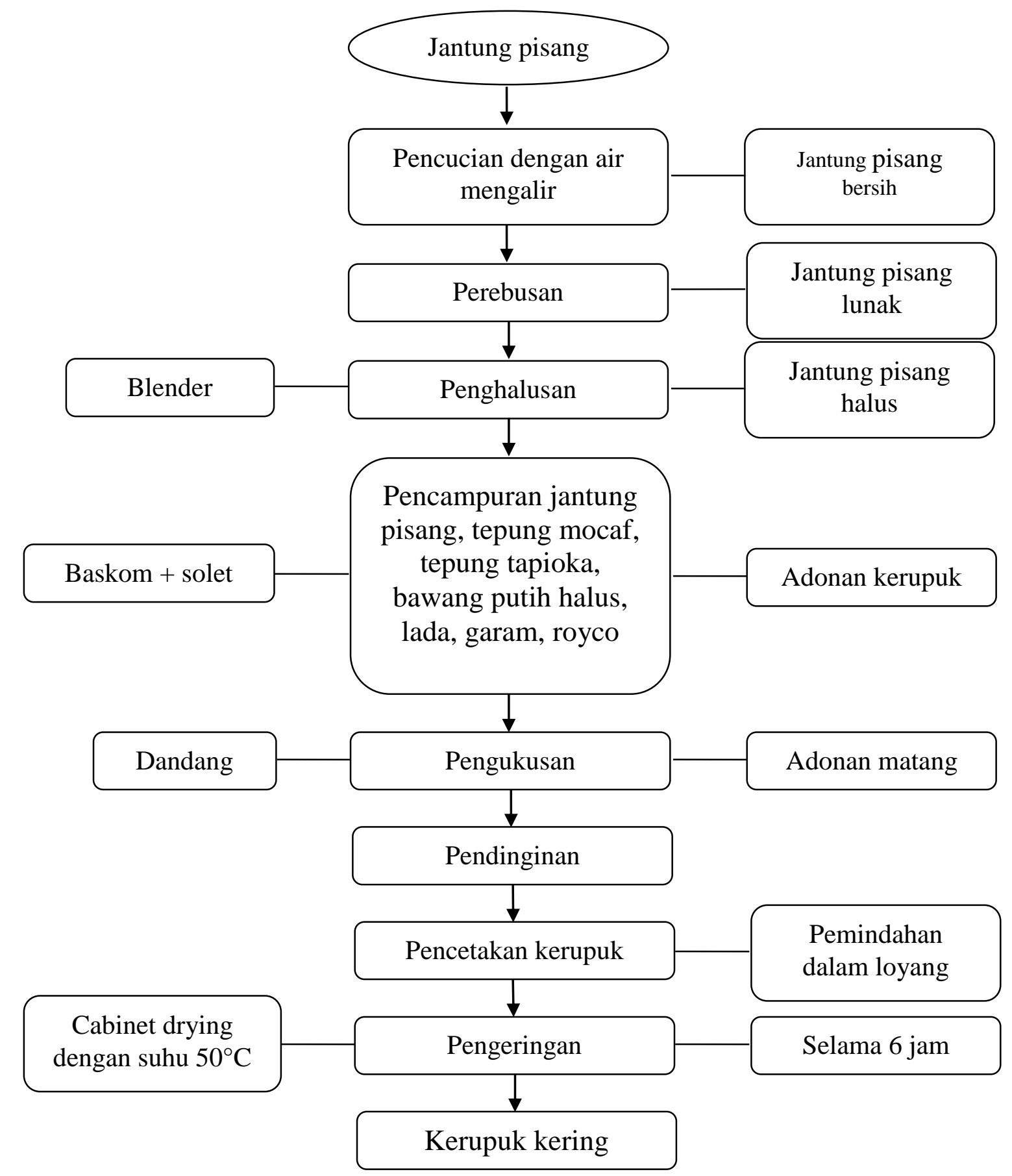

Gambar 1 Diagram Alir Proses Pembuatan Kerupuk Jantung Pisang Mocaf

Sumber : Novitasari Afifah dkk (2013) proses pembuatan jantung pisang kepok yang sudah termodifikasi.

\section{HASIL DAN PEMBAHASAN}

Produk kerupuk jantung pisang mocaf terbuat dari jantung pisang kepok yang dicampur dengan bumbu-bumbu dan tepung mocaf.

\section{Karakteristik Kimia Kerupuk Jantung Pisang Mocaf}

Karakteristik kimia produk kerupuk jantung pisang mocaf berdasarkan analisa kandungan protein, kadar air dan serat kasar.
Adapun data hasil analisa kimia dapat dilihat pada Tabel 1.

Tabel 1 Data Hasil Analisa Kimia Kerupuk Jantung Pisang Mocaf

\begin{tabular}{|c|c|c|c|}
\hline No & $\begin{array}{c}\text { Jenis } \\
\text { Analisa }\end{array}$ & Metode & Hasil \\
\hline 1 & Kadar air & $\begin{array}{l}\text { Oven kering } \\
\text { (thermogravimetri) }\end{array}$ & $2,00 \%$ \\
\hline 2 & Protein & Titrasi formol & $0,37 \%$ \\
\hline 3 & Serat kasar & r Ekstraksi & $7,00 \%$ \\
\hline
\end{tabular}


Hasil analisa kadar air dengan metode oven kering (Thermogravimetri) kerupuk jantung pisang mocaf menunjukkan $2 \%$ merupakan kadar yang rendah. Kadar air dipengaruhi oleh kadar air awal bahan, apabila kadar air semakin rendah maka akan semakin mudah menyerap air (Mahmudah, 2017).

Kadar air adalah persentase kandungan air suatu bahan yang dapat dinyatakan berdasarkan berat basah (wet basis) atau berdasarkan berat kering (dry basis). Kadar air berat basah mempunyai batas maksimum teoritis sebesar 100 persen, sedangkan kadar air berdasarkan berat kering dapat lebih dari 100 persen (Syarif dan Halid, 1993).

Kadar air merupakan pemegang peranan penting, kecuali temperatur maka aktivitas air mempunyai tempat tersendiri dalam proses pembusukan dan ketengikan. Kerusakan bahan makanan pada umumnya merupakan proses mikrobiologis, kimiawi, enzimatik atau kombinasi antara ketiganya. Berlangsungnya ketiga proses tersebut memerlukan air dimana kini telah diketahui bahwa hanya air bebas yang dapat membantu berlangsungnya proses tersebut (Tabrani, 1997).

Metode pengeringan dengan oven yaitu dilakukan penguapan air dari bahan dengan cara memberikan energi panas. Kemudian menimbang bahan hingga berat bahan konstan. Penentuan kadar air di pergunakan untuk mengetahui dan menentukan tingkat mutu atau kualitas dari suatu bahan. Metode analisa kadar air dengan menggunkana oven berdasarkan pada gravimetric dan sesuai untuk bahan-bahan yang berbentuk kering atau serbuk (Anonim. 2010, dalam Fitria, R. H. 2011 : 16)

Kadar Protein dengan analisa Tritasi Formol menunjukkan kadar protein 0,37\%. Hal ini berbeda dengan penelitian dendeng jantung pisang diketahui kandungan proteinnya adalah $12,051 \%$, karbohidrat $34,831 \%$, lemak total 13,050\% (Mansyur, 2013). Menurut Daftar Komposisi Bahan Makanan (2018) jantung pisang mengandung 1,20 gram protein (per 100 gram). Protein merupakan salah satu kelompok bahan makronutrien. Tidak seperti bahan makronutrien lain (lemak dan karbohidrat), protein berperan lebih penting dalam pembentukan biomolekul dari pada sebagai sumber energi. Namun demikian, apabila organisme sedang kekurangan energi, maka protein ini terpaksa dapat juga digunakan sebagai sumber energi. Kandungan protein rata-rata 4 kilokalori/gram atau setara dengan kandungan energi karbohidrat (Sudarmadji. 1989, dalam Fitria, R. H. $2011: 17$ )

Kadar serat kasar dalam kerupuk jantung pisang sebesar 7,00 \%. Serat kasar adalah bagian dari karbohidrat yang telah dipisahkan dengan bahan ekstrak tanpa nitrogen (BETN) yang terutama terdiri dari pati, dengan cara analisis kimia sederhana (Tillman et al., 1989). Serat kasar terdiri atas selulosa, hemiselulosa dan lignin. Fraksi serat kasar dapat diukur berdasarkan kelarutannya dalam larutan-larutan detergen, yaitu menggunakan analisis Van Soest (Tillman et al., 1989). Menurut Sutardi (1980), analisa Van Soest merupakan sistem analisis bahan makanan yang lebih relevan manfaatnya bagi ternak, khususnya sistem evaluasi nilai gizi hijauan.

\section{Karakteristik Sensori}

Analisis sensori dari produk kerupuk jantung pisang mocaf meliputi penilaian dari segi rasa, warna, tekstur, bentuk dan kenampakan keseluruhannya. Adapun data hasil penilaian analisis sensori dapat dilihat pada Tabel 2.

Tabel 2 Data Hasil Analisis Sensori

\begin{tabular}{cccccc}
\hline \multirow{2}{*}{ 20 Panelis } & Warna & Rasa & Tekstur & Bentuk & $\begin{array}{c}\text { Kenampakan } \\
\text { keseluruhan }\end{array}$ \\
\cline { 2 - 6 } & 104 & 120 & 116 & 94 & 114 \\
\hline Total skor & 5,2 & 6 & 5,8 & 4,7 & 5,7 \\
Rata-rata & 5
\end{tabular}

Rentang skor penilaian adalah skor $1=$ sangat tidak suka, $2=$ Tidak suka, $3=$ agak tidak suka, $4=$ netral, $5=$ agak suka, $6=$ suka, $7=$ sangat suka. 
Berdasarkan analisa sensori pada 20 orang panelis menunjukkan rata-rata skor kesukaan terhadap warna adalah 5,2 artinya responden agak suka warna kerupuk jantung pisang mocaf. Rata-rata skor rasa adalah 6 menunjukkan responden suka rasa kerupuk jantung pisang mocaf. Rata-rata skor tekstur 5,8 menunjukkan responden suka. Bentuk rata-rata skornya 4,7 menunjukkan agak suka. Rata-rata keseluruhan penampakan 5,7 menunjukkan responden suka pada kerupuk jantung pisang mocaf.

Warna dari kerupuk jantung pisang mocaf adalah kuning bersih dan sedikiti kecoklatan menjadi pengaruh mengapa panelis agak suka terhadap kerupuk jantung pisang mocaf. Warna tersebut dipengaruhi oleh proses penggorengan terhadap kerupuk.

Rasa bersifal kompleks dan terkait dengan rasa suatu produk. Rasa terdiri dari beberapa elemen diantaranya asin, manis, pahit dan gurih. Rasa dari kerupuk jantung pisang mocaf menjadi atribut utama yang sangat mempengaruhi terhadap penerimaan konsumen. Dari hasil analisis sensori kerupuk jantung pisang mocaf yang dilakukan terhadap produk kerupuk jantung pisang mocaf dapat dilihat pada tabel 4.2, rata-rata panelis suka terhadap rasa dari kerupuk.

\section{Desain Kemasan}

Dalam suatu produk diperlukan label kemasan untuk memberikan informasi tentang keadaan produk pada konsumen atau masyarakat. Label pada jantung pisang mocaf dapat dilihat pada gambar 4.2.

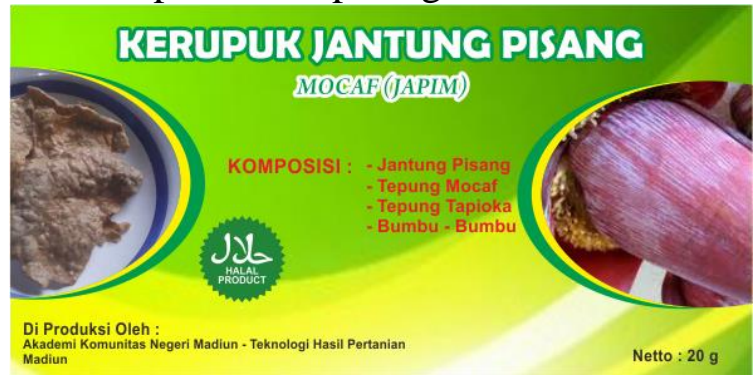

Gambar 2 Label Kerupuk Jantung Pisang Mocaf

\section{Bahan}

Bahan pengemasan yang digunakan untuk mengemas kerupuk jantung pisang mocaf adalah plastik pp (polipropilen), pp merupakan plastik berkilat dan jernih dengan sifat optik dan daya rentang yang baik dan tahan terhadap sobekan.

Karakteriktik dari pp yaitu ;

a) Kuat, ulet, ringan dan transparan.

b) Proteksi baik terhadap uap air dan tahan terhadap reaksi kimia.

c) Tidak beracun, ramah lingkungan dan stabil pada suhu tinggi.

\section{Bentuk}

Pengemasan kerupuk jantung pisang mocaf yang menggunakan plastik $\mathrm{pp}$ berbentuk persegi panjang. Pengemasan produk menggunakan mesin pengemas hand sealer dengan tujuan untuk mencegah kontaminasi udara luar denagn produk yang akan mempercepat kerusakan pada produk.

\section{Pelabelan (labelling)}

Pelabelan pada produk kerupuk jantung pisang mocaf terdiri dari judul, netto. Kandunagn dan produsen produk, label halal dan masa kadaluarsa. Pelabelan ini bertujuan untuk mempromosikan produk terhadap konsumen. Dalam pelabelan kerupuk jantung pisang mocaf menggunakan stiker.

\section{KESIMPULAN}

1. Karakteristik kimia kerupuk jantung pisang mocaf dengan beberapa analisis sebagai berikut : mengandung protein sebesar 0,37\%, kadar air sebesar 2,00\% dan kadar serat kasar sebesar 7,00

2. Karakteristik kerupuk jantung pisang mocaf dari dari segi organoleptik sesuai dengan analisis sensori yang dilakukan panelis memberikan penilaian warna skor 5,2 (agak suka), rasa skor 6 (suka), tekstur skor 5,8 (suka), bentuk skor 4,7 (agak suka) dan secara keseluruhan suka (rata-rata skor 5,7) terhadap kerupuk jantung pisang mocaf.

\section{SARAN}

Untuk kelanjutan dari pembuatan kerupuk jantung pisang mocaf perlu adanya tindakan atau hal-hal yang perlu diperhatikan diantaranya :

a. Perlu adanya penyediaan bahan baku yang lebih dengan kualitas yang lebih baik.

b. Perlu adanya inovasi untuk meningkatkan penampilan warna dan bentuk kerupuk 
jantung pisang mocaf sehingga lebih menarik perhatian konsumen.

\section{DAFTAR PUSTAKA}

Mahmudah. Nuraini. Amanto, Widowati, 2013, Karakteristik Fisik, Kimia dan Sensori Flakes Pisang Kepok Samarinda (Musa paradisiacal bilbisiana) dengan substitusi pati garut, Journal ITP FP UNS, http://journalitp.uns.ac.is diakses 2 Oktober 2018 13.00.

Mansyur, 2013, PKM Dendeng Jantung Pisang, http://www.habibmansyurblogspot.com /2013/06/contohprogramkreatifitas mahasiswa.com diakses 8 Oktober 2018 .

Novitasari dkk., 2013.http://ejournal.uajy.ac.id/9139/3/2BL01214.pd f Diakses pada 25 Maret 2017.

Nuramanah, 2012. http://eprints.ung.ac.id/5488/5/2013-184204-441409033-bab2-

31072013121141.pdf. Diakses pada 25 Maret 2017.

Panji,R.2012.http://download.portalgaruda.or g/article.php?article $=153487 \& v a l=547$ 9\&title=Inovasi\%20dari\%20Jantung\% 20Pisang\%20(Musa\%20spp.). Diakses pada 25 Maret 2017.

Satuhu,Supriyadi,2001.http://repository.usu.a c.id/bitstream/123456789/42447/4/Cha pter\%20II.pdf. Diakses pada 30 Maret 2017.

Steenis, 2003 dalam Martiningsih, 2007 http://eprints.ung.ac.id/5488/5/2013-184204-441409033-bab2-

31072013121141.pdf. Diakses pada 25 Maret 2017

Sulandari, 2016. Proposal tugas akhir pembuatan nugget jantung pisang mocaf. Di akses pada 15 Mei 2017.

Sunarjono,2000.http://repository.usu.ac.id/bit stream/123456789/42447/4/Chapter\%2 OII.pdf. Diakses pada 30 Maret 2017.

Suyanti,Supriyadi.2008.http://ejournal.uajy.ac.id/9139/3/2BL01214.pd f. Diakses pada 25 Maret 2017.

Suyanti dan Supriyadi, 2008. http://eprints.ung.ac.id/5488/5/2013-1- 84204-441409033-bab2-

31072013121141.pdf. Diakses pada 25 Maret 2017.

Syarif dan Halid, 1993.http://eprints.ung.ac.id/3180/3/20 12-1-1002-612309025-bab210082012043452.pdf. di akses pada 18 Mei 2017.

Tillman.et.al.,1989.http://repository.ipb.ac.id/ jspui/bitstream/123456789/59957/5/B AB\%20II\%20Tinjauan\%20Pustaka.pd. di akses pada 18 Mei 2017. 